\title{
THE THOUGHT OF KH IMAM ZARKASYI ON MULTICULTURAL EDUCATION AT MODERN ISLAMIC BOARDING SCHOOL GONTOR PONOROGO
}

\author{
Fisher Zulkarnain \\ State Islamic University (UIN) Sunan Gunung Djati Bandung, Indonesia \\ Jl. A. H. Nasution No. 105, Bandung, West Java \\ Email: fisher_uin@yahoo.com
}

\begin{abstract}
KH. Imam Zarkasyi is one of the founders of Islamic Boarding School "Darussalam" Gontor (PMDG) and at once became a national figure. Author describes multicultural education in the perspective $\mathrm{KH}$ Imam Zarkasyi, then take measurements on the practice of multicultural education in PMDG. This study suggests, since KH. Imam Zarkasyi PMDG founded in 1926 have established an atmosphere of multicultural education are covered by the system of formal curriculum and daily life activities. Under the existing system, Pondok Modern Gontor potential to develop multicultural education insightful and worthy of being an example of successful implementation of multicultural education in Indonesia. It can be seen from classroom practice, exchange dormitory, five principal of boarding, interaction between the consulate, and the synthesis of education applied in Pondok Modern Gontor for many years.
\end{abstract}

Keywords: Gontor, Multiculturalism, and Islamic Education.

\section{ABSTRAK}

KH. Imam Zarkasyi adalah salah satu pendiri Pondok Pesantren Modern Gontor (PMDG) dan sekaligus menjadi tokoh nasional. Penulis medeskripsikan definisi pendidikan multikultural dalam perspektif KH. Imam Zarkasyi, kemudian melakukan pengukuran mengenai praktik multikulturalisme pendidikan di PMDG. Penelitian ini menunjukkan, sejak awal berdiri tabun 1926 PMDG telah menancapkan atmosfir pendidikan multikultural yang tercakup dalam sistem kurikulum formal dan aktivitas pergaulan sehari-hari. Dengan sistem yang ada, Pondok. Modern Gontor sangat potensial mengembangkan pendidikan berwawasan multikultural dan layak menjadi contoh sukeses implementasi pendidikan multikulturalisme di Indonesia. Ini bisa dilihat dari praktike pembelajaran di kelas, pertukaran penghuni asrama, panca jiwa pondok, pergaulan antar konsulat, dan sintesa pendidikan yang diterapkan di Pondok Modern Gontor bertahuntabun.

Kata Kunci: Gontor, Multikulturalisme, dan Pendidikan Islam. 


\section{INTRODUCTION}

Reporting of International Center for Islamic and Pluralism (ICIP) is interesting to observe. Throughout the years 2005-2006 ICIP research the 20 schools in West Java than 2200 schools joined in Boarding School Cooperation Agency in Indonesia (BKSPPI). The objective, is to test whether pesanten (Islamic boarding school) approve of violence and intolerance toward the differences? The themes studied discourse about multiculturalism, such as tolerance, democracy, gender and Islamic law. The results showed, understanding a number of pesantren in West Java, has not been fully able to accept the reality of multiculturalism. Review and report published in the journal $A l-W$ asathiyyah Indonesian and English edition in January 2008.

Followed by Malindo Institute research (2008), titled Religion and Potential Conflicts: Studies of Islamic Boarding School in Indramayu view of leadership, Cirebon, Kuningan, Majalengka, Ciamis about Jihad, Violence, and Power. In multicultural values of variables that occur in society, among them the action of demolition of houses of worship without permission, said Malindo research, as many as 33\% of respondents who agreed. While there are $47 \%$ of respondents disagree.

While the remaining $20 \%$ of respondents expressed doubt that the non-Muslim houses of worship were built without permits must be destroyed. Explicitly, Islam appealed to his people to respect diversity and differences as well as demanding that they contribute positively in the context of diversity in order to get to know each other (QS. Al-Hujurat [49]: 13). This paper discusses how a Islamic boarding school, to develop strategies and models of multicultural education, including through the curriculum and daily activities that ultimately multicultural education can be implemented.

In the book published Islamic Boarding School Directory Ministry of Religion (2002), records all boarding schools in Indonesia amounted to 14 656 units. Of this amount can be divided into three patterns or typologies boarding school. First, schools that have a traditional style reached 9,105 schools or $62 \%$. Pesantren traditional patterned generally are boarding that has long existed and still retains its traditional style. Secondly, schools that have a modern style, the number reached 1,172 schools, or $8 \%$ of the total number of schools in this country. Third, the number of schools with an integrated pattern or blended the school system reaches $30 \%$ of the existing boarding schools.

Seeing the large numbers and strong influence in society, of course, helped bolster boarding life of the nation, especially in terms of peace and tolerance. Islamic boarding schools consistently maintaining the tradition of 
peace, balance, harmony of the environment, thereby potentially minimizing social conflict that often occurs in Indonesia. In doctrinaire boarding school continued to develop principles ukhuwah Islamiyah, ukhuwah wathaniyah, and ukhuwah basyariyah in an effort to strengthen the architecture of the Unitary Republic of Indonesia (NKRI) as well as participating in the development of global governance peaceful life.

This is reflected in the educational model in Pondok Modern Gontor, Ponorogo, East Java. In view of KH Imam Zarkasyi, founder, Pondok Modern Gontor is the educational institution that is ideal for generating cadres of the people (Biography KH Imam Zarkasyi, 1996). With a system to boarding, boarding a living environment that is characterized by simplicity souls, wkhumwah Islamiyya (Islamic brotherhood), sincerity and independence. Besides boarding is also capable of cultivating an attitude, outlook and philosophy of life for the benefit of the students in the future. Similarly pesantren education in the faith, piety, and morality can be done effectively. In the development of boarding modern Gontor can realize the hopes of Muslims in Indonesia as an educational institution that is able to generate a cadre of people through the development of multicultural values. This can be seen from the alumni Pondok Modern Gontor that filled strategic institutions in the country.

According to our informant interviews, boarding life upholds respect, regardless of ethnic origin, ethnicity, race and class. Curriculum schools, both modern and traditional boarding schools, teaching students increase national awareness on the environment and society so that they can live together and co-exist with a diverse group of plural Indonesian society and be able to spread mercy for the environment.

The term multiculturalism is defined by experts in diverse and multidimensional. Thesis Amin Nurdin (2009), for example, declared multiculturalism a principled social order of justice and equality that reflects the value of the various cultures and ethnic groups. The concept of multiculturalism emphasizes the live view of the reality of diversity, plurality and multicultural on people's lives. In the implementation of multicultural education concepts successfully manage conflicts as indicated by the low variety of potential political violence, ethnic, and religious.

In the context of multicultural education in Pondok Modern Gontor, as the theme of this discussion, multicultural is the acceptance of diversity of human cultural expression in understanding the main message of religion, regardless of the details teaching. Its main base is explored on the basis of Islam, because Islam became the basis of the distinguishing dimensions.

In fact, Imam Zarkasyi emphasized more on moral element than the intelectual one, as demonstrated in his daily life and personality (Rahardjo, 
1996, p. 858). This was shown in the boarding school mottos which represent the full reflection of the principle which he believed in and fought for; that he placed moral above other elements. The mottos are noble character, healthy body, broad knowledge and freedom of thought.

Imam Zarkasyi prioritized peace full above other abilities. This proves that moral, according to him is an important element in education particularly at Modern Islamic Boarding School - and even in society because it involves humans' ideology that teaches and prepares students in facing future challenges.

Consequently, the graduates of Modern Islamic Boarding School are well-accepted by the national and international communities, and some of them have been entrusted with important position in different institutions. Some of them have become prominent figures such as Lukman Hakim Saifuddin (Minister of Religious Affairs, Indonesia), Hasyim Muzadi (former Chairman of Nahdlatul Ulama), Din Syamsuddin (former Chairman of Muhammadiyyah), Hidayat Nurwahid (former Chairman of People's Consultative Assembly), Idham Khalid (former Chairman of Nahdlatul Ulama), Nurcholish Madjid (Muslim scholar) and others.

Indeed to stop and protect the younger generations from the negative influences of globalization, moral education has become an essential path that one has to take. As mentioned above, Imam Zarkasyi established a concept to mould students' characters and manners. He successfully applied this concept at his institution and the concept is still being used by current leaders to inculcate in students good character and good manners. Therefore, the basic thing to be expressed in this paper is the definition of multicultural education according to Imam Zarkasyi at Modern Islamic Boarding School.

The purposes of this study are as follows: (1) to discover KH. Imam Zarkasyi's point of view on the multicultural education, (2) to explain the kinds and measurements of multicultural according to KH. Imam Zarkasyi, and (3) to identify the ideal method of inculcating multicultural according to KH. Imam Zarkasyi's point of view.

This is biography research which looks at the educational background, character, environmental influences as well as ideas and thoughts of a person. This approach observes the biography of Imam Zarkasyi, his works, conditions in which possibly influenced his characteristics. This approach is a method of collecting data, making interpretation and conclusion on the historical background based on documents as its sources.

This method is used as a systematical description on facts and characteristic of a certain population or in an actual and accurate sector (Hasan, 2002, p. 22). The writer employed this method to describe the thoughts of Moral Education experts, particularly in the thinking of $\mathrm{KH}$. 
Imam Zarkasyi. This is a method of collecting data and facts, which are to be discussed and illustrated systematically, factually, and validly based on the data. The writer used the library research technique to study Imam Zarkasyi's works, in order to select data on his thoughts and to obtain the complete description of his ideas on moral education. After finding the data, the writer categorized them qualitatively with the appropriate procedure and technique.

The data was analysed used, (1) Inductive. This is a method to conclude a specific statement (Hasan, 2002, p. 22). This method was employed to draw general conclusions from the thoughts of Imam Zarkasyi on Moral Education. (2) Analytic-critical. In this method, all collected facts and arguments were discussed and analyzed critically and then compared between one another.

\section{ANALYSIS AND DISCUSSION \\ Brief biography of KH Imam Zarkasyi}

KH Imam Zarkasyi, born in the Gontor village, Ponorogo, East Java, on March 21, 1910. Less than age 16, Imam Zarkasyi initially studied at several schools in his native region, such as Josari Pesantren, Pesantren Joresan and Pesantren Tegalsari. After completing his studies at the School Ongkoloro (1925), he continued his studies at the boarding school Jamsaren, Solo. At the same time he also studied at the School Manba'ul Ulum. Then continued his studies at the School Arabiyah Adabiyah led by KH MO AlHisyami, until 1930. During the study in these schools (especially schools Arabiyah Adabiyah) he was very interested in studying Arabic language lessons.

While studying in Solo, teachers at most filling, Imam al-Hasyimi, is a scholar, political figures and writers from Tunisia once exiled by the French Government in the area of Dutch colonization, and eventually settled in Solo.

After completing his education in Solo, Imam Zarkasyi to continue his studies in Kweekschool, Padang Panjang, West Sumatera, until 1935. After graduation in Kweekschool, he was asked to become the director of the University by his teacher, Mahmud Yunus. But Imam Zarkasyi only be able to meet the demand and confidence for one year (1936), with consideration even though it was fairly high positions, but he felt that the job is not the main goal after studying in that place. Imam Zarkasyi assessed by Mahmud Yunus has a talent that stands out in the field of education, but he noticed that more Gontor require his presence. In addition, his brother Ahmad Sahal are working hard to develop education in Gontor not allow Imam Zarkasyi linger outside the educational environment Gontor. 
After handing over his post as director of Education Kweekschool to Mahmud Yunus, Imam Zarkasyi back to Gontor. In 1936 it also, even ten years after declaring Gontor as an educational institution with a new style, Imam Zarkasyi soon introduce a new educational program called Kulliyatu-l Mu'allimin Al-Islamiya (KMI) and he himself acted as director.

Subsequently in 1943 he was asked to become the head of the Office of Religious residency of Madiun. During the Japanese occupation, he was active in leading squad Hezbollah, in Bekasi, West Java. After Indonesia's independence, Imam Zarkasyi also active in the Ministry of Religious Affairs especially the Directorate of Religious Education at that time minister HM Rasyidi. Energy and thoughts are also much needed in the Ministry of Education and Culture when Ki Hajar Dewantoro served as minister.

Other important positions occupied Imam Zarkasyi in the middle of busy life as an educator at the Institute of Education Gontor was as Head of Religious Education Ministry of Education Research Committee members in 1946. Furthermore, for 8 years (1948-1955) he mandated to be the Chairman of the Executive Board of the Union Teachers Islam Indonesia (PGII) the secretary at that time held by KHEZ Muttaqin and subsequently became an adviser PGII.

Imam Zarkasyi also served as Head of the Planning Division of Religious Education at the Ministry of Religious Primary School (1951-1953), Head of the Supervisory Board of Religious Education (1953), Chairman of the Advisory Council of Education and Religion (MP3A) Ministry of Religious Affairs, Planning Board Member Education Basic Rules Private Ministry of Education (1957). Additionally in 1959, Imam Zarkasyi appointed as a Member of the National Planning Council by the President Soekarno.

In the international arena, Imam Zarkasyi once a member of the Indonesian delegation in the review to the countries of the former Soviet Union, in 1962. Ten years later, he also represented Indonesia in Mu'tamar Majma 'Al-Bubuth al-Islamiya (Islamic Academics Mu'tamar the World), the 7th that took place in Cairo. In addition, he also became the head quarter of Advisory Council of Indonesian Ulama Council (MUI).

Besides being known as an activist in the field of education, social and political state, Imam Zarkasyi also quite productive in the field of writing. In this regard, he left a lot of scientific work and his writing can be read until today. This is consistent with his remark of the opening KMI in 1936, he said: "if I had not managed to teach in this way, I will teach with the pen."

Among the writings of Imam Zarkasyi is Senjata Penganjur dan Pemimpin Islam, Pedoman Pendidikan Modern, Kursus Agama Islam. The third book is written along with $\mathrm{KH}$ Zainuddin Fanani. Furthermore, he wrote 
Ushuluddin (lessons Aqo'id or Belief), Fiqih I and II, Tajwid, Bimbingan Keimanan, Qowaidul Imla', Babasa Arab I and II, Tamrinat I, II and III, along with his dictionary and books Other textbooks.

In addition Imam Zarkasyi also written several technical guidance for the students and teachers in Pondok Darussalam Gontor in various issues related to education at the school, including methods of teaching multiple subjects. Books written by him are still used in KMI Gontor Pondok Modern Darussalam Islamic boarding schools and alumni of Gontor as well as some religious schools. On 30 April 1985 at 21:00 pm Imam Zarkasyi passed a way in General Hospital Madiun, leaves a wife and 11 children.

\section{Glance Pondok Modern Gontor}

In one room boarding Modern Gontor there is a portrait of the old frame written in 1926. Some Islamic leaders seem to pose together behind a sign that reads "Al-Islamiyah". Historic meeting Congress of Muslims of Indonesia in Surabaya in mid 1926 Gontor this new history begins. The congress was attended by figures Indonesian Muslims, for example HOS Cokroaminoto, Kyai Mas Mansur, H. Agus Salim, AM. Sangaji, Usman Amin, and others. There was an event difficult to find a messenger who mastered two foreign languages at once, Arabic and English, which will be sent to the Congress Islamic Worldwide in Mecca (Suryanegara: 2009).

This event has inspired Kyai Ahmad Sahal and participants of the congress, on his way back to Madiun. Which later became a serious topic of conversation among brothers who want to uphold of his inheritance boarding founded by his grandfather.

Gontor is a name of the village in the southern town of Ponorogo who has the meaning of "enggon" (place), and "ntor" (stands dirty). So Gontor was once a dirty place, where "mo-limo" ([maen] gambling, [madat] opium or drug consumption, [madon] womanizing, [maling] thief or steals, [mabok] drunkenness).

On the 12th of Rabi al-Awwal 1345 or 20 September 1926, Pondok Gontor revived by three brothers, namely; Kyai Ahmad Sahal, Kyai Zainuddin Fananie, and Kyai Imam Zarkasyi. All three as the founder of the famous "Trimurti" boarding. The goals revived by three brothers, according to a German researcher Lance Castle, who visited Gontor in 1965, is based on a sense of responsibility to continue and develop the task predecessors in spreading the science of Islamic religion and culture, reviving the schools that have been collaps and make it as a new model of Islamic schools in Java (Lance, 1991, p. 30).

In the history of the boarding, the goal is the re-establishment of this boarding; to continue and enhance efforts earlier scholars in disseminating 
knowledge and Islamic culture. The dream that far ahead, passing through space and time, of which only aim to restore people's consciousness towards the right path. To strengthen the educational institutions, was inspired the idea to combine the teachings of boarding school education system with the theory and practice of modern education. The model was reffered from AlAzhar University, Aligarh, Santineketan, and Sekolah Taman Siswa.

To realize his ideas, the founders chosed reviving Gontor that had been abandoned by their fathers. Gontor established on the heritage and traditions of the noble boarding schools that are integrated with the systems and methods of modern education (Zarkasyi, 2005: 101). In that sense, the ideals, spirit and philosophy of life following a system dormitory still refer to the treasury of the Islamic world, but its implementation is done effectively and efficiently with characterizing the system modern boarding, armed with values, philosophy, orientation on which the formulation of the vision, mission, and objectives as illustrated below:

Table: 1

\begin{tabular}{|c|c|c|}
\hline VALUE & FIVE PRINCIPLE OF BOARDING & MOTTO \\
\hline & Sincerity & Noble character \\
\hline & Simplicity & Healthy body \\
\hline & Self reliance & Broad knowledge \\
\hline & Islamic brotherhood & Independent mind \\
\hline & Freedom & \\
\hline PHILOSOPHY & PHILOSOPHY OF INSTITUTION & $\begin{array}{ll}\text { PHILOSOPHY } & \text { OF } \\
\text { EDUCATION } & \end{array}$ \\
\hline & $\begin{array}{l}\text { Pondok Modern Gontor is stand } \\
\text { above and for all groups }\end{array}$ & $\begin{array}{l}\text { Being intellectual ulama and } \\
\text { not intellectual knowing } \\
\text { religion }\end{array}$ \\
\hline & $\begin{array}{l}\text { Pondok Modern Gontor is a field of } \\
\text { battle, not a place to make a profit }\end{array}$ & $\begin{array}{l}\text { Live is once, live } \\
\text { meaningfully }\end{array}$ \\
\hline & $\begin{array}{l}\text { This pondok is a waqf for the muslim } \\
\text { ummah and is not the property of } \\
\text { Kiai any more. }\end{array}$ & $\begin{array}{l}\text { Ready to be leaded and } \\
\text { ready to lead }\end{array}$ \\
\hline
\end{tabular}

The education system Gontor has adopted the best prototype of educational institution in the world. There were four ideal institution in this regard:

Table: 2

\begin{tabular}{|l|l|l|}
\hline No & \multicolumn{1}{|c|}{ INSTITUTION } & \multicolumn{1}{c|}{ OBJECTIVES } \\
\hline 1 & Al-Azhar in Egypt & $\begin{array}{l}\text { Al-Azhar University is known as the center of Islamic } \\
\text { knowledge in the Muslim world and was highly reputed } \\
\text { with its survival for centuries due to its waqf property. } \\
\text { Al-Azhar University provide scholarship to muslim } \\
\text { student from all over the world. }\end{array}$ \\
\hline 2 & Syanggit in Mauritania & Syanggit was a well known institution, not only for its \\
\hline
\end{tabular}




\begin{tabular}{|l|l|l|}
\hline No & INSTITUTION & \multicolumn{1}{c|}{ OBJECTIVES } \\
\hline & & $\begin{array}{l}\text { boarding system but also for the sincerity of its founders } \\
\text { and teachers, and their hospitality as well. Located in a } \\
\text { remote area in Mauritania and under the guidance of its } \\
\text { founding father Sidi Abdullah, it could accommodate } \\
\text { around 3000 to 5000 students with full scholarship. }\end{array}$ \\
\hline 3 & Shantiniketan in India & $\begin{array}{l}\text { Shantiniketan was basically a traditional boarding school } \\
\text { that belongs to Rabindranath Tagore, a Hindu } \\
\text { philosopher and noble prize winner. Shantiniketan } \\
\text { etymologically means abode of peace. In this institution } \\
\text { teachers and students learn together in a milieu that is } \\
\text { fully designed for education. }\end{array}$ \\
\hline 4 & Aligarh in India & $\begin{array}{l}\text { It was founded in 1920 under the name Mohammedans } \\
\text { Anglo Oriental Collage by Sir Syed Ahmad Khan but } \\
\text { later it became first university in India, it main objectives } \\
\text { was to revive the Muslim ummah by the inclusion of } \\
\text { knowledge through education. }\end{array}$ \\
\hline
\end{tabular}

It was because of its objective that Gontor made it a model for the future of Islamic education. So the ideal educational institution envisioned by Gontor was an Islamic educational institution that was to be the center of learning for Islamic studies, which could generate its own fund and able to give scholarship to its student. This institution shoul be driven by the spirit of sincerity, simplicity, brotherhood, self reliance, and accountable freedom, and other Islamic spirits which are instrumental for one's religious and worldly life. By this spirits and principles the institution could hopefully be a world class educational institution.

Bringing with the hopes and ideals of the founders were far ahead, they are determined to bring a new educational model for the nation. In fact, on October 12, 1958, this boarding officially donated to the ummah. The boarding is no longer private property. For the sake of a sacred ideal, all descendants of the founders are not deserved to inherit property and material of this boarding. But they were allowed to engage in it, according to its capacity, to assist and fight for boarding.

Thus, further strengthen the ideals and expectations of the Trimurti forward in realizing the center of exelence science and Islamic studies in a boarding school-based educational institutions.

Estafeta leadership is currently in the hands of the second generation. Although at first many doubted, but its achievements to date has given signals of positive development and progress. If the measured quantity of students, the number of students at the last moment the leadership of Trimurti in 1985 amounted to only 1,250 students. Begining 1990 already two to three times. To meet the capacity and accommodate the wishes of the parents who want to send their children to boarding school, Pondok Gontor 
open its branches. With the increasing number of students each year means that a model like Gontor gain public confidence.

Currently there are 15 branch boarding in the archipelago. The number of students according to data secretariat boarding 2014-2015 school year totaled approximately 20,000 students. The courage of Gontor not modeled with boarding schools at the time and did not follow the model of education that is required to the government agency is not recognized by the government for 80 years. Gontor has experienced difficult times such up and down the number of students, an accused of secular wing, and was stopped when the uprising PKI activities. However, there are hard times there is also privellege, several universities abroad precisely recognizes graduates and alumni Gontor. Shortly after the reform era, issued the acknowledgment that Gontor equal with public schools at the same level.

At present, after the passed away of the last Trimurti, K.H.Imam Zarkasyi in 1985, Gontor has survived well and has been properly maintained under the dynamic leadership of KH Abdullah Shukri Zarkasyi, MA., KH Hasan Abdullah Sahal and KH. Syamsul Hadi Abdan. Its property has been successfully developed. Gontor today has fifteen branches to fulfill the demand of society by using the same curriculum, the same method and the same values with the total students more than 20.000. Bambang Saeful Maarif, Gontor 1980 alumnus who currently serves as Dean of the UNISBA Bandung said:

Once of the factor Gontor progress role of their alumni in community. The alumni Gontor performed with confidence, because they practice the education, training and discipline in Gontor. Particularly alumni who trained directly by KH Imam Zarkasyi (1901-1985). Gontor boarding can move forward until now because of consistently adhered to the tradition and values at boarding.

Pondok Modern Gontor who have credo "Pondok Modern Gontor is stand above and for all groups". No wonder, if the alumni Gontor freely choose to take part anywhere, in the sense that no doctrinal against normative profession line taken.

As a result, alumni are varian color. To merely mention, there is a model teacher of nation Nurcholish Madjid (alm), thinker sociologist Yudi Latif, Hasyim Muzadi (NU chairman), Din Shamsuddin (Muhammadiyah chairman), the cultural observer Emha Ainun Nadjib, hardliner movement Abubakar Baasyir, controversial educator Panji Gumilang, as well as politicians such as Hidayat Nur Wahid (PKS), Zainun Ahmadi (PDIP), Zaenal Ma'arif (Democratic Party), until the antigraft body (KPK) leaders Adnan Pandu Pradja. Not to mention the many prominent alumni who rarely 
appears on television, but their work is recognized in the wider community. And it added to the diversity of alumni Gontor treasures.

Gontor village that was once only famous as a black area, is now a name that is known as excellent center of Islamic education. Gontor was able to penetrate the boundaries Gontor located in the southern corner of City Ponorogo. That situation would not be separated from the ideals and spirit of its founders. This is expressed by Amsal Bakhtiar who had been Vice Chairman Organization of Student Pondok Modern Gontor (OPPM) a kind of council in high school, period 1978/1979. Amsal which is currently Director of Islamic Higher Education of the Ministry of Religious Affairs, said:

At least four factors that cause Pondok Modern Gontor established as it is today. First, the genuine commitment of the leadership, so Pondok Modern Gontor always goes on the track. Second, the education system and teaching more advanced than the educational system comparing to the time of the founding of Pondok Modern Gontor. Gontor has started a classical teaching systems, evaluation of measurable, and introduce language teaching actively and directly. Third, the building is quite magnificent and sturdy, far from being traditional buts. Thus the building impression convinced the trustees to add reliability Pondok Modern students will Gontor manage quality education. Fourth, the alumni who are already active in various religious and social fields. As mentioned above, this last factor is increasingly the name of Gontor boarding on the national stage.

\section{Multicultural Concepts in Education}

Multiculturalism is the understanding and perspective that emphasizes interaction by considering the existence of every culture as an entity that has equivalent rights. The multicultural concept is emerging normative ideas about harmony, tolerance, mutual respect for differences and the right of each culture of a nation (UI Anthropology Team, 2007: 3).

The demand of the importance multicultural education were voiced by thinkers and writers of education in Indonesia meet a positive response from the executive as well as legislative. Its approved with the bill of national educational system of Republic of Indonesia Number 20 Year 2003, which accommodate the values of human rights and multicultural spirit. In fact, these values serve as one of the principles the organization of National Education, as embodied in Chapter III Article 4: "Education is held in a democratic and fair and not discriminatory to uphold human rights, religious values, cultural values, and the diversity of the nation."

Multicultural education as an educational thinking emerged and developed since the 80 s until the beginning of the 21 st century model of multicultural education history from America that is now being adopted by 
many developed countries. This is due to the view that our country has now advanced to the model of multicultural education. For that other developed countries are interested to adopt the system. According to James A. Banks (2001: 28), multicultural education is a concept, idea or philosophy as a series of confidence (set of believe) and an explanation that recognizes and assesses the importance of cultural and ethnic diversity in shaping the lifestyle, social experiences, personal identity, educational opportunities from individuals, groups and nations. That is, the multicultural education trying to integrate all the elements of social beliefs and culture into a single color without distinction of race or any race.

Zakiyuddin Baidhawy (2005, p. 5) in his book Religious Education Multicultural Perspective say that multiculturalism is understood a group of people from diverse cultures permanently coexist with one another. Multiculturalism emphasizes the importance of learning about other cultures, trying to understand them fully and emphatically, multiculturalism implies a necessity to appreciate other cultures. That is, one can not impose his will and must respect other people's thoughts, either in truth or error. Furthermore, Zakiyuddin believe that when the people living close together, there is no necessity of interaction between cultures. And no one who lives completely isolated. Education is very powerful in introducing multicultural world where they become part of it, like it or not. Multicultural education is a emergency need. The point is the implementation of multicultural understanding who wants to generalize the degree of correctness is a necessity and an obligation.

Thus, multicultural education in the end is a way to teach diversity (teaching diversity). Multicultural education requires rationalization ethical, intellectual, social and pragmatic inter-relative that teaches the ideals of inclusiveness, pluralism and respect for all people and cultures is imperative humanistic which is a prerequisite for life ethical and civic participation fully in democratic, multicultural and human world diverse. Integrating the study of facts, history, culture, values, structure, perspective and contribution of all groups into the curriculum so that it can build to enrich knowledge, complex, and accurate information on humanitarian conditions within and across context of time, space and certain culture.

The vision of a multicultural religious education dialogical approach to instill awareness of living together in diversity and difference. Education is built on the spirit of the relationship of equality, mutual trust, mutual understanding and respect for similarities, differences and uniqueness, and interdepedensi. This is an innovation and an integral and comprehensive reform in charge of religious education; which give new construction of knowledge about religions that are free of prejudice, racism, bias, and 
streotipe. Multicultural religious education provides recognition of the plurality of means, learning and transforming indoctrination to dialogue (Anwar, 2008, p. 93).

In more detail, there are several aspects that can be developed from the concept of Islamic education multicultural as stated by Ngainun Naim and Achmad Sauqi (2008, p. 53-54), as follows: (1) Islam multicultural education is education that respects and embraces all forms of diversity. It is expected to grow wisdom in seeing all forms of the existence of diversity; (2), Islam multicultural education is a sistematic effort to build understanding, and awareness of students to the reality of a pluralist-multicultural. This is important, because in the absence of a systematic effort, the reality of diversity will be understood sporadic, fragmentary, or even will bring extreme exclusivity. (3) Islam multicultural education does not force or reject students because identity issues of ethnicity, religion, race, or class. They are derived from a variety of differences must be positioned equally, egalitarian and given the right medium to appreciate the characteristics they have. Under these conditions, no one is superior to one of the students with other students. Each has the same position, and should obtain equal treatment; (4) Islam multicultural education provides an opportunity for growth and development of a sense of self to each of the students. It is important to build confidence, especially for students who come from economically disadvantaged, or a group that is relatively isolated.

Islamic education was inspired by the idea of Islam multicultural transformative always oriented efforts to realize the ideals of Islam, namely the shape and change society to the ideals of Islam: bring mercy to all the worlds (Nata, 2002, p. 79). With reference to this end, Islam multicultural education aims to create a society of peace, tolerance and mutual respect to the basis of the values of the divine. It must needs be that innovation and curriculum reform in multicultural education is not only touching the knowledge transfer process (transfer of knowledge), but also provide experience and skills (sharing experience and skills), including in religious education.

Within this framework of religious education needs to consider various matters relevant to the cultural diversity of the community and students. Teachers should reflect the religious lives of learners and the particular and diverse. Religious education will be more effective when new ideas are organically related to the previous knowledge and early taught in ways that are familiar to students (Baidhawyi, 2005, p. 40).

Finally, multicultural education based on the idea of social equality in education will never contrary to Islamic doctrine. In the teachings of Islam has clearly instructed not to discriminate against ethnic, racial, etc., including 
in education. All humans are the same, the difference is only piety to Allah. Multicultural in Islamic education also reflects how the high appreciation of Islam to the science.

\section{Model of Multicultural Education in Gontor}

Right now, it has grown thousands of boarding schools in the archipelago, which can be broadly classified into two main systems: the traditional pesantren (salafiyah) and modern pesantren. The hallmark of boarding traditional is consistency in implementing the education system is pure and is not bound formality instruction (classes) and level of education and a diploma. Pesantren these models also tend to specialize in the study of religious sciences. While modern pesantren seeks to combine modernity traditionality and education. Classical-style system of formal teaching (teaching in the classroom), and integrated curriculum was adopted with certain a djustments. The dichotomy of religion and general knowledge also eliminated. Both disciplines are equally taught, but the proportion of religious education dominate. An education system that is used in modern boarding called Mu'allimin system.

In the context of Pondok Modern Gontor, real multiculturalism education has become basic education is not only taught in formal teacher in the classroom alone. But it is also done in the everyday life of students. Formal education multiculturalism embodied in the form of teaching material "keindonesiaan" or citizenship has curricular. Teaching systems in modern boarding-dominated foreign languages (Arabic and English) as an introduction, do not release the spirit multiculturalism education students (students). Because this material is placed as a primary material and must be taught by the Indonesian media as well.

In the field of non-formal education schools with an excess of intense 24-hour, had plenty of time to insert a variety of education. One of them multiculturalism. The general pattern that was almost enacted in various modern boarding is a multicultural educational system that integrates the rules and discipline of the boarding. One of them in matters of placement quarters (dormitories) students. In modern Islamic boarding, not imposed a permanent placement of students in a dormitory. In a sense, all students must undergo a systematic shift to another hostel, in order to foster their social life to diversity.

Education in Pondok Modern Gontor regulations stipulate that each year students are required to transfer the dorm. Every semester they will also experience a shift in the dormitory they inhabit. It is intended to provide variety of life for the students, also guides them expand relationships and opened their minds to the various traditions and cultures of other Islamic 
student (santri). Placement of students not based on region of origin or the tribe. In fact, the placement has been arranged by the caretakers boarding, and maximally pursued santri small probability of occupying a certain area of the same room.

According to the boarding Islamic regulation, the rooms may not be occupied by a maximum of 3 people over student from the area. According to Abdullah Syukri Zarkasyi (2005, p. 125), this attempt to merge the spirit of regionalism them into a more universal spirit. In addition, in order that students may also study the broader social life, national, and even international with the foreign students. However, the application of this education pattern, according to Syukri Zarkasyi, does not mean denying the element area. Because the regional element has been accommodated in the activity area called "consulates", which provisions of the organization and its activities have been arranged, in particular to reject the a source of regional fanaticism.

Other multiculturalism education in the intensity of modern boarding education is the imposition of binding rules that prohibit students speak the local language. In addition to the main languages Arabic and English, when students enter the cabin environment is only allowed to speak Indonesian in several occasions and interests. Disciplining students in education through the language of multiculturalism is very tight. For those students who break them will be given sentences ranging educative.

Education condensed tolerance for differences also taught in the education system of modern boarding. The diversity of thought to students without compulsory, or teach them to impose ideas. The stance of tolerance highly appreciate at modern education system boarding. Mu'allimin system supported with education intensity 24 hours, load Kurikulum Berbasis Kompetensi (competency based curriculum), as required in formal education, can be passed modern boarding. At the KBK, the main constraint is the limited teaching time to give a full understanding of a material to students. With Mu'allimin system, the period of extracurricular in the boarding school were more likely than formal learning time in the classroom. The limitation period of teaching in this class can be handled by boarding school with a lot of free time which can be used to supplement the teaching of teachers to students. This pattern is efficiently and effectively for the teaching at the boarding. In addition there is no dichotomy between extracurricular and intracurricular, Zarkasyi (2005, p. 125).

The discource curriculum as in the books at-Tarbiyah wat Ta'lim also attracted all components of education including (learning sources) and the creation of educational milieu that support for the achievement of educational ideals. Trimurti Pondok Modern Gontor in carrying out 
education refers to one book At Tarbiyah wat Taliim likely formerly taught in Kweek School, Thawalib Padang Panjang. As is known teacher of KH Imam Zarkasyi, is Mahmud Yunus was a graduate of Egypt progressive in his time. Modern education thoughts that he developed in Kweek School is a curriculum that much inspired and adopted from curriculum at Al Azhar. All learning materials almost in Arabic except for English lessons. This is because he strongly emphasized the need for mastery of tools, namely Arabic and English. Regarding this curriculum, Tasirun Sulaiman, alumni of Gontor 1983, argues as follows:

"The alumni Pondok Modern Gontor there may be experiencing in his day, that math, Al-Ajabar and Measurement Science, on the past use of the Arabic language. And that's what keeps students in Pondok. Modern Gontor really sunk. in environment linguistic tremendous. In explaining new vocabulary in both Arabic and English using the same word in Arabic and English. So, in Pondok Modern Gontor no vocabulary Indonesian translation in his teaching. Al-Munjid Dictionary and Oxford Advanced Dict, must be required KMI fifth grade students of Pondok Modern Gontor must have both a dictionary and also should be able to use it".

Other subjects containing the multicultural topics and normative components of civil society are History of Islamic Culture, Quran and Hadith Studies, and Fiqh. In History, there is one topic, peaceful preaching of Prophet Muhammad in Mecca and Medina. Whereas in Quran and Hadith Studies, there are four topics: democratic principle in QS. Ali Imran: 159, and QS. Asy-Syura: 38; suggestion to compete for good deed as mentioned in QS. al-Baqarah: 148 and QS. al Fatir: 32; an order to help dhu afa (the poor) in QS. al-Isra: 26-27 and QS. al-Baqarah: 177; and suggestion for being tolerant as in QS al-Kafirun: 1-6, QS. Yunus: 40-41, and QS. al-Kahfi: 29. In Figh there are 6 topics under multicultural and normative components of civil society perspectives, they are: legacy in Islamic law; marriage in Islamic law; corpse management; economic transaction in Islam; rakat, philanthropy, and pilgrim management; and (6) law of religious obligation (taklifi) in Islam.

Education virtue of multiculturalism in modern boarding is also reflected in the curriculum subtle diversity teaches students understanding of belief. In the field of study Dirasah Islamiyah group, for example, taught special material Muqaranat al-Adyan (Comparative Religion) which describes the extent of the content of history, doctrine, ism, religious phenomena and dynamics in the world. This material is very substantial in multicultural education, because students understood various fundamental differences in their religious beliefs (Islam) with other religions in the world. This material is very potential to build awareness of diversity tolerance belief that the 
students will encounter when living in a society in the future. Openness to understand the religions outside of Islam are introduced through "Adyan" subjects. The lessons given to students who started fifth grade II or grade level madrasah aliyah was reviewing various different religious teachings. By doing so, students and islamic teacher do not hesitate to get along with people of other religions.

In this case Helmi Hidayat, alumnus of Pondok Modern Gontor 1983 and graduated of Oxford University, London, said:

"When school is equipped in our Gontor ilmul-mantiq (the science of logic). For Gontor is a great school and a moderate. In the equivalent class II junior class, we were taught Imam Shafi'i figh. Understandably the majority of Indonesian people mazhab Syafii. But in the fourth grade equivalent of the first high school, we were tanght Bidayatul Mujtabid of Ibn Rushd. We were tanght all the schools and that means we are tanght to think. freely and insightful. They were also taught the science of religion (al-adyaan). Even in the third grade junior high school they were taught the philosophy of Socrates, Plato and Aristotle. From here it should be all the alumni Gontor be moderate and tolerant because after all, since the very teen age, they are already accustomed to thinking philosophically, free, and not bound blind fanaticism groups."

In education multikulturalism attitude, modern boarding implement routine understanding through visualization of various cultures and culture his students. Each new school year held a big ceremony Khutbatul Arsy (introducing of the boarding) with any of the material events in the form of performances of various cultural creations all the elements of students, by category "consulates" (regional). In this event contested demonstration uniqueness and cultural treasures of the place of domicile of origin of students. All students are required to engage in this activity. These activities at the opening a new school year is intended to enlightening the understanding cultural diversity in the environment.

While welcoming the new school year, through Kbutbatul Arsy, the students should associate with the pop culture that contains, among other vocal competitions. At that moment, the students sang popular songs. They are able playing the guitar, drums, or keyboard. Gontor life is very mobile. The students also adopted western culture, including the American pop icon. It's far away from the image of traditional islamic boarding: such as traditional boarding, wich is isolated at the remote area.

The openness of Pondok Modern Gontor was not only visible from the lifestyle of his students, but also integrated in the education system, the use of languages, and touch with the neighboring. The boarding not only teached the Islamic knowledge, but also introduced at every level of general 
knowledge, such as physics, mathematics, or biology. Everyday, the students spoke in Arabic and English. They are trained to master two languages in order to combine religion and general knowledge.

Table 3. Model of Curriculum Content

\begin{tabular}{|l|l|l|l|l|}
\hline No & $\begin{array}{l}\text { SUBJECT } \\
\text { SCIENCE }\end{array}$ & MATTER SUBJECT & GRADE & OBJECTIVES \\
\hline 1 & $\begin{array}{l}\text { Ilmu Mantiq } \\
\text { Science of } \\
\text { Logic). }\end{array}$ & $\begin{array}{l}\text { Explores the many } \\
\text { basic science of logic } \\
\text { level } \\
\text { inspired by the ideas } \\
\text { of Aristotle, Socrates, } \\
\text { and Plato. }\end{array}$ & Class III & $\begin{array}{l}\text { Training and } \\
\text { educating students in } \\
\text { developing the } \\
\text { potential of mind by } \\
\text { using the } \\
\text { methodology of } \\
\text { thinking. }\end{array}$ \\
\hline 2 & $\begin{array}{l}\text { Muqaranat al- } \\
\text { Adyaan } \\
\text { (Comparative of } \\
\text { Religion). }\end{array}$ & $\begin{array}{l}\text { Describes the history, } \\
\text { doctrine, streams } \\
\text { (ism), phenomena and } \\
\text { religious dynamics in } \\
\text { the world. }\end{array}$ & Class V & $\begin{array}{l}\text { To stipulate the } \\
\text { motto PM Gontor } \\
\text { (knowledgeable), so } \\
\text { that students are } \\
\text { familiar to looking } \\
\text { the variety and } \\
\text { dynamic of thinking. }\end{array}$ \\
\hline 3 & $\begin{array}{l}\text { Bidayat al- } \\
\text { Mujtabid (Ibn } \\
\text { Rushd, who was } \\
\text { born in Cordova, } \\
\text { 520 H / 1125 } \\
\text { AD) }\end{array}$ & $\begin{array}{l}\text { The book explain the } \\
\text { diversity arguments } \\
\text { related Jurisprudence, } \\
\text { whether conceptual or } \\
\text { textual vission since } \\
\text { the period of sahabat } \\
\text { until the 11th century } \\
\text { AD }\end{array}$ & Class V & $\begin{array}{l}\text { The student are } \\
\text { taught all schools in } \\
\text { slam in order the } \\
\text { student thought free } \\
\text { and appreciate the } \\
\text { differences of } \\
\text { opinion. }\end{array}$ \\
\hline
\end{tabular}

Table 4. Model of Multicultural Activity Student

\begin{tabular}{|l|l|l|l|l|}
\hline No & SYSTEM & \multicolumn{1}{|c|}{ ACTIVITY } & CLASS & \multicolumn{1}{|c|}{ OBJECTIVES } \\
\hline 1 & $\begin{array}{l}\text { Khutbatul } \\
\text { Arsy }\end{array}$ & $\begin{array}{l}\text { introduction to islamic boarding } \\
\text { life carried out the beginning of } \\
\text { each new school year. }\end{array}$ & All Students & $\begin{array}{l}\text { To introduce the } \\
\text { students how } \\
\text { there are living } \\
\text { in Pondok } \\
\text { Modern Gontor. }\end{array}$ \\
\hline 2 & Consulate & $\begin{array}{l}\text { Each of the students has a } \\
\text { "consulate" where they are } \\
\text { coming from. The fact, the } \\
\text { student must associated with } \\
\text { various consulates. }\end{array}$ & all Students & $\begin{array}{l}\text { Knowing each } \\
\text { other student } \\
\text { including the } \\
\text { origin cultura } \\
\text { and their islamic } \\
\text { mainstream }\end{array}$ \\
\hline 3 & $\begin{array}{l}\text { Foreign } \\
\text { Language }\end{array}$ & $\begin{array}{l}\text { Using of Arabic and English as } \\
\text { second daily language }\end{array}$ & All Students & $\begin{array}{l}\text { To master the } \\
\text { language of } \\
\text { Arabic as the } \\
\text { basic and of } \\
\text { Islamic religion }\end{array}$ \\
\hline
\end{tabular}




\begin{tabular}{|l|l|l|l|l|}
\hline No & SYSTEM & \multicolumn{1}{|c|}{ ACTIVITY } & CLASS & \multicolumn{1}{|c|}{ OBJECTIVES } \\
\hline & & & $\begin{array}{l}\text { and English as } \\
\text { the international } \\
\text { language }\end{array}$ \\
\hline 4 & Dormitory & $\begin{array}{l}\text { All student are forced staying at } \\
\text { dormitory and will be exchange } \\
\text { each semester }\end{array}$ & $\begin{array}{l}\text { Class I-IV } \\
\text { To exchange the } \\
\text { new atmosphere, } \\
\text { new friends, new } \\
\text { group, and } \\
\text { inevitable } \\
\text { fanaticism }\end{array}$ \\
\hline
\end{tabular}

\section{CONCLUSION}

Religious-based educational institutions, particulary Pondok Modern Gontor an institution that empowers multicultural education. Pondok Modern Gontor not only emphasis on religious education alone. However, it also provides an extra education in building the character and developing the capacity of a person based on the chacarter of kinship, diversity, tolerance and peace.

In the frame of Pondok Modern Gontor, educational vision of tolerance manifested in two forms: (1) through the curriculum, which is manifested in the form of teaching material of citizenship has been included on curricular. (2) In everyday life, the tolerance and multicultural education system are integrated in the rules and disciplines.

The essence of multiculturalism is the creation of pluralism, by emphasis on respecting differences between individual beliefs, unconsciously students have been taught how religion from the perspective of multiculturalism and pluralism. Certainly understand as this is very dangerous, it is possible the students will doubt the truth of Islam. And this is desired by the understanding of multiculturalism promoted by the West.

\section{BIBLIOGRAPHY}

Ali, Mukti, A.H., (1991) Ta'lim al-Muta'allim versi Imam Zarkasyi, , Gontor: Trimurti.

Baidhawy, Zakiyuddin., (2005), Pendidikan Agama Berwawasan Multikultural, Jakarta: Erlangga.

Bakhtiar, Amsal., (2006), Gontor: Masa Kini dan Tantangan Masa Depan, dalam kolom Majalah Gontor, edisi 80 tahun PM Gontor.

Castles, Lance., (1996). Note on Islamic School at Gontor, transleted by Hamid Fahmy Zarkasyi, Gontor, sebuah catatan lama tentang sekolah Islam, Gontor: Trimurti Press.

Hasan, Iqbal., (2002). Pokok-pokok Materi Metodologi Penelitian dan Aplikasinya, Jakarta: Ghalia Indonesia. 
ICIP (International Centre for Islam and Pluralsme), Jurnal Al-Wasathiyyah, No.1 edisi Januari 2008.

Interview Bambang Saeful Maarif., (2015), alumni Pondok Modern Gontor 1979

Interview Helmi Hidayat., (2015), alumni Pondok Modern Gontor periode 1983

James A. Banks (ed)., (2001). Handbook of Research on Multicutural Education, 2001

Malindo Institute: For Social Research and Islamic Development, (2008), Agama dan Potensi Konflik: Studi terhadap Pandangan Pimpinan Pesantren di Indramayu, Cirebon, Kuningan, Majalengka, Ciamis dan Pangandaran tentang Jihad, Kekerasan dan Kekuasaan. Final report.

Mastuhu., (1994), Dinamika Sistem Pendidikan Pesantren, Jakarta: INIS.

Naim, Ng dan Sauqi, Achmad, (2008), Pendidikan Multikultural Konsep dan Aplikasi. Jogjakarta: Ar-Ruzz Media Group.

Nata, Abudin., (2002), Pemikiran Para Tokoh Pendidikan Islam. Jakarta: RajaGrafindo Persada.

Nurcholish Madjid., (1985), Merumuskan Kembali Tujuan Pendidikan Pesantren, dalam Dawam Raharjo (ed) Pergulatan Dunia Pesantren: Membangun dari Bawah, Jakarta: P3M.

Nurdin, M. Amin., (2009). Pergulatan Kaum Muslim Minoritas Australia Islam Versus Multikulturalisme dan Sekularisme, Jakarta: Ushul Press.

Rahardjo, Dawam., (1996), Karakter al-Ustadz Imam Zarkasyi dan Kebebasan Pondok Modern Gontor (sebuah Refleksi), Biografi KH. Imam Zarkasyi di mata ummat, Gontor: Gontor Press.

Suryanegara, A. Mansur., (2009), Api Sejarah, Bandung: Grafindo Salamadani.

Tim Antropologi UI., (2007), Gagasan Multikulturalisme dalam Pendidikan Agama di Indonesia.

Tim Penulis., (2005) Sejarah Balai Pendidikan Pondok Modern Darussalam Gontor, Ponorogo: Trimurti Press.

Tim Penulis., (1990). Kenang-kenangan 1926: Peringatan Delapan Windu, Gontor: Trimurti Pres.

Tim Penyusun., (2006) Biografi KH Imam Zarkasyi dari Gontor Merintis Pesantren Modern, Ponorogo: Gontor Press.

Tim Penyusun., (1996). Biografi K.H. Imam Zarkasyi, Dari Gontor merintis Pesantren Modern, Gontor: Gontor Press.

Tim Penyusun., (1996). Biografi K.H. Imam Zarkasyi, Di Mata Umat, Gontor: Gontor Press.

Wawancara Tasirun Sulaiman., (2015), alumni Pondok Modern Gontor 1984

Yaqin, M. Ainul., (2005), Pendidikan Multikultural, Cross-Cultural Understanding untuk. Demokrasi dan Keadilan, Yogyakarta: Pilar Media. 
Zarkasyi, Abdullah Syukri., (2005). Manajemen Pesantren Pengalaman Pondok Modern Gontor, Ponorogo: Trimurti Press.

Zarkasyi, Imam, Dikat Pekan Perkenalan, Serba-serbi serba singkat, Gontor: Darussalam Press, (nd).

Zarkasyi, Imam, Jagalah Ijazah Akblak, Majalah Gontor; Edisi 06 tahun II, Sya'ban 1425/Oktober 2004, Gontor: Darussalam Press, 2004.

Zarkasyi, Imam, Jiwa-jiwa Keikhlasan dan Perjuangan, Gontor: Darussalam Press, 1424

Ziemek, Manfred., (1986), Pesantren dalam Perubahan Sosial, Jakarta: P3M. 